\title{
A Multicultural Citizenship Education Program Through a Virtual Learning Environment Platform: A Greek Study Under the EU ISOTIS Project
}

\author{
Konstantinos N. Vasileiadis PhD (Corresponding author) \\ Head-teacher, $16^{\text {th }}$ Primary School of Evosmos, Greece \\ E-mail: kostas.vasiliadis@gmail.com
}

Evdoxia D. Kompiadou, PhD candidate

Kindergarten teacher, $14^{\text {th }}$ Kindergarten of Sykies, Thessaloniki, Greece

E-mail: ekompiad@gmail.com

Konstantinos A. Tsioumis, Professor

School of Philosophy and Education, Aristotle University Thessaloniki

Thessaloniki, Greece

E-mail: ktsioumi@edlit.auth.gr

Konstantinos Petrogiannis, Professor

School of Humanities, Hellenic Open University, Patras, Greece

E-mail: kpetrogiannis@eap.gr

Received: December 15, 2019 Accepted: January 14, 2020 Published: February 5, 2020

doi:10.5296/ijld.v10i1.16041ＵRL: https://doi.org/10.5296/ijld.v10i1.16041 


\begin{abstract}
The article presents the activities taken place to design and implement activities that meet the criteria, aims and goals of ISOTIS project that aims to contribute to effective policy and practice development at different system levels in order to effectively combat early arising and persisting educational inequalities. We focus on the procedures and theoretical framework that the Greek team, as partner of ISOTIS project adopted to support diverse families both linguistically and culturally, to create effective and inclusive curricula and moreover to develop educational policy to combat educational inequalities. In this paper we introduce the criteria for selecting the sites according to the demographic and their pedagogical characteristics, the teacher's experience, the children's needs and the main issues, challenges and arguments for the co-design phase and the main principles and shared ideas according to ISOTIS criteria. This paper highlights positive family/parent-teacher interactions through ICT technologies, fostering to improve and promote inclusiveness and belongingness. Our theoretical framework lays in critical multicultural citizenship education and democratic governance in schools.
\end{abstract}

Keywords: Citizenship education, Multiculturalism, Education policy, VLE

\title{
1. Introduction
}

The current paper briefly presents one of the sub-studies undertaken in Greece as part of ISOTIS, a large scale European project. The main aims of ISOTIS project is to contribute to effective policy and practice development at different system levels in order to effectively combat early arising and persisting educational inequalities. ISOTIS will do so by generating evidence-based, contextualized and concrete recommendations and tools for: (1) supporting disadvantaged families and communities in using their own social, cultural and linguistic resources to create safe and stimulating home environments for their children; (2) creating effective and inclusive curricula and pedagogies in early childhood education and care centres and primary schools; (3) professionalization of staff, centers and schools to improve quality and inclusiveness; (4) establishing inter-agency coordination of support services to children and families; and (5) developing national (state-level) policies to combat educational inequalities (see www.isotis.org).

By viewing classrooms and schools as a two-level institutional context for social change, and by providing the appropriate framework to promote and accelerate new ideas, there is a strong belief that teachers can play an important role in assisting students develop critical thinking, collaboration and self-reflection skills so that they can become "political actors" able to "change the society". Based on the critical multicultural citizenship as the principal supporting theoretical perspective for the current study, it is acknowledged that education has long been regarded as a key institution for the development of democratic citizens, particularly through citizenship education. Critical multicultural citizenship education encourages the contestation of existing knowledge and critical thinking (Banks, 2008; May, 1999; Nieto, 1999). Critical multiculturalism pushes beyond traditional multiculturalism in that it promotes democratic programs and lesson plans to be used in curriculum, pedagogy, and social relations in school settings (McLaren, 2003). 
Critical multiculturalism fosters empathy and active participation in a diverse society by supporting efforts toward attaining sociocultural and emotional accord. It promotes pluralism, an appreciation of diversity, and provides teachers, students, and learners with tools to critique relationships between power, knowledge, and other oppressive discourses. The connection between knowledge, power, re-examination, and transformation is explicit in critical multiculturalism (May \& Sleeter, 2010; McLaren, 2003; Sleeter \& Grant, 1994).

A first way to achieve this aim and encourage students to become 'political actors for social change' is to create a safe, encouraging place and a community of conscience. Within this line of thought, school community of conscience becomes an educational environment where students' voices, opinions and ideas are valued and respected by teachers, peers and other members of the school community (e.g. parents).

By using an ecological systems approach as well (see, for example, Bronfenbrenner \& Morris, 2006) we consider the individual, the microsystem (including patterns of activities, social roles, and interpersonal relations), the mesosystem (focusing on connecting school and families as well as professionals), and exosystem elements (focusing on mobilizing external resources to support schools and professionals) of the educational process as contexts to be transformed and at the same time as resources. We also aim at describing and providing key features and facilitators that are both useful and meaningful so that we can achieve our goals (classroom practices, positive school and classroom climate, educational and pedagogical approaches based in critical multicultural theory).

The paper brings examples of classroom positive interactions and also study material that supports the importance of family involvement approaches and improvement of teachers' academic performance. The virtual platform made and used by the ISOTIS program brings findings reflecting on parents and children, fostering communication and interaction with parents from other cultures and also from the dominant culture, aiming to promote inclusiveness and belongingness. Parents across ISOTIS program valued the experience of respecting their heritage languages and got familiar with education settings that support multiculturalism.

\section{Criteria for Selecting the Sites}

Some of the basic issues that concern the Greek educational context and shape the context for designing the intervention, especially with reference to the selection of the sites, concern:

i. the curriculum and other steering documents that provide mandates for the educational process: The Greek curriculum is highly structured with very little flexibility for educators to adapt to children's and families' needs. As a result, teachers are restricted in their efforts to promote and implement innovative practices. According to Flouris and Passias (2003:77-78) "school programs in Greece consist of a core or "mainline" subjects'.... '...The curriculum is characterized by internal incoherence concerning educational goals, curriculum content, and textbooks".

On the contrary, the curriculum in early childhood settings, for children aged from 4 to 6 years, is considered flexible and not strictly structured. As mentioned in the revised curriculum for the 
kindergarten (Institute of Educational Policy, 2014:7), it is considered as "a dynamic tool in the hands of the teacher, describing not only the content and the goals to achieve but also the appropriate pedagogical practices for an inclusive education for all'.

ii. the issue of parental involvement and use of ICT: At the school level, there is lack of 'culture of participation' regarding parents. This means that parents are not actively involved in educational programs and school activities. As Lazaridou and Kassida (2015) state, parental involvement in schools "tends to be less than satisfactory" even if latest school reforms emphasize 'the notion of parental involvement as a significant factor for the effectiveness of the Greek schools'. Additionally, based on the everyday experience with the parents, it seems that they are not quite familiar with the ICTs and a lot of effort is needed by schools to engage them in communicating and interacting using technology for educational purposes.

iii. the cultural background of the families: Greece is a country with an already high percentage of immigrants. From a traditionally sender country following the WWII period, Greece has become a main destination country for immigrants from Central and Eastern Europe and the former Soviet Union from the early 90s onwards as well as African and Middle East countries in the 2000s, according to I.O.M. report for Greece (UN Migration, 2019). According to a number of sociodemographic surveys of national institutions such as the 2001 census (National Statistical Service of Greece, 2001), the Migration Policy Institute (e.g., Kassimis \& Kassimi, 2004) and ELIAMEP studies (e.g., Gropas \& Triandafyllidou, 2005), the percentage of immigrants residing in the country is estimated to be $10 \%$. The participation of immigrants to the total population is $17 \%$ in the Municipality of Athens and $7 \%$ in the Municipality of Thessaloniki (Baldwin-Edwards, 2005). It should be noted that immigrants in Central Northern Greece are mainly from the Balkan countries, which constitutes the main reason for focusing on this area when studying Greek national identity in the context of the so-called 'new' migration (Xenitidou, 2007). In addition, since 2015, more than 1 million people arrived in the EU, most of them fleeing from war areas and terror in Syria and close by regions. 167,000 people have arrived in Greece in the period between January and October 2016 of whom 147,000 had arrived in the period between 1 January- till 20 March 2016 (Triandafyllidou \& Mantanika, 2016).

The refugee population that entered the country is not homogeneous. According to data from the General Secretariat for Media and Communication on refugee arrivals in 2016, 46\% came from Syria, 24\% from Afghanistan, 15\% from Iraq, 5\% from Pakistan and 3\% from Iran. In addition, $64 \%$ of them are men and $36 \%$ are women. A characteristic feature of the refugee population, which is of crucial importance in designing an education program is the fact that there is a very high number of young people under $18 ; 24.5 \%$ of men and $31.9 \%$ of women fall in this broad age group (Scientific Committee in Support of Refugee Children, 2017).

Based on these facts it was decided the selected sites to be from the region of western Thessaloniki. The sites were selected due to:

- the high percentage of immigrants and ethnic minorities that reside in this particular region (the number of these groups has been increasing in recent years due to the high migration waves towards Greece), 


\section{Macrothink Institute ${ }^{\mathrm{TM}}$}

- the intense socio-economic inequalities (working class area, with a majority of ingenious population facing the effects of economic crisis)

- the fact that these specific sites are hosting refugee families moving from camps to urban sites established for hosting vulnerable families and asylum seekers.

\subsection{Demographic characteristics of the sites}

Two classes were selected from the $16^{\text {th }}$ Primary School of Evosmos-Thessaloniki with students attending Grade 1 (6-7 years age). In addition, a kindergarten class was selected from the $14^{\text {th }}$ Kindergarten in Sykies.

Table 1 briefly presents the main demographic characteristics of the groups of children.

\begin{tabular}{llll}
\hline Selected site & \multicolumn{1}{c}{$\begin{array}{c}\text { Population of } \\
\text { immigrants/refugees }\end{array}$} & $\begin{array}{c}\text { Population of } \\
\text { low income }\end{array}$ & Profile of community \\
\hline $\begin{array}{l}14^{\text {th }} \text { Kindergarten } \\
\text { of Sykies }\end{array}$ & $20 \%$ & $35 \%$ & $\begin{array}{l}\text { High percentage of } \\
\text { immigrants and refugees } \\
\text { and low-income population }\end{array}$ \\
\hline $\begin{array}{l}16^{\text {th }} \text { Primary } \\
\text { school of }\end{array}$ & $5 \%$ & $34 \%$ & $\begin{array}{l}\text { High percentage of } \\
\text { immigrants and refugees } \\
\text { avosmos }\end{array}$ \\
\hline
\end{tabular}

\subsection{Pedagogical Characteristics of the Sites}

Two members of the research team were working as teachers in the selected schools from the two sites. Additionally, the teachers that were chosen and voluntary committed to implement the program had extensive teaching experience with multicultural classes. Additionally, these schools provide a clear intercultural policy and support a model of a school that promotes the principles of equality and respect in all aspects of education and fosters the concept of equal access to full education for all pupils.

In the selected schools a distinct school policy exists, determined by the educational legislation and the planning reflects the decisions of the Director and the Teachers' Association that are shared with parents, guardians and students of the school. The school policy aims to establish a learning community, constantly evolving, so that all members of the school community acquire the necessary life skills and readiness to meet the challenges posed in everyday life (see Note 1). According to the school policy the students are expected to work collaboratively on projects, and there is a substantial focus on project work interdisciplinary across traditional subjects.

The participating classrooms could be typically described as "learner-centered". The teachers have pedagogical autonomy in the classroom and are considered as pedagogical experts. They 


\section{Macrothink}

(i) are entrusted with considerable independence in the classroom, and (ii) have decision-making authority as concerns the school policy and management.

The contradiction encountered is that according to the National Curriculum for primary schools, teachers have limited responsibility for the choice of textbooks and teaching methods. Nowadays, efforts are underway so that teachers and schools have more autonomy in planning and using various pedagogical approaches and methods.

In the kindergarten the school policy has a more collaborative and interactive character, according to the preschool settings (small group of professionals that cooperate very closely) and to the age of the children. We mostly refer to the school climate, rather than the school policy, that reflects the needs of the children and their families. In the Greek preschool context children develop their personal identity and autonomy through child centered practices and thematic approaches that focus on socio-emotional skills development, while teachers design programs, choose teaching strategies and organize learning experiences to meet children's different needs. Preschool teachers organize the classroom in order to support co-operation as well as individual work. Family and the broader community play a crucial role in children's learning. Communication with parents is critical to the implementation of such an approach.

Moreover, in the selected schools (see Table 2), through our policy and the school climate, in collaboration with parents and students, the researchers focused on constructing a climate of trust between educators and the community and collective school responsibility for learners who are struggling.

Table 2. Schools' pedagogical approach and educational characteristics

\begin{tabular}{|c|c|c|c|c|c|c|}
\hline Site & Typology & $\begin{array}{c}\text { Existing } \\
\text { School } \\
\text { policy }\end{array}$ & $\begin{array}{l}\text { Pedagogical } \\
\text { approaches }\end{array}$ & $\begin{array}{c}\mathrm{N}^{\mathbf{0}} \text { of } \\
\text { teachers }\end{array}$ & $\begin{array}{c}\text { Total } \\
\text { No of } \\
\text { students }\end{array}$ & characteristics \\
\hline $\begin{array}{l}16^{\text {th }} \text { Primary } \\
\text { school of } \\
\text { Evosmos }\end{array}$ & public & Yes & $\begin{array}{l}\text { Learner-Centred } \\
\text { Pedagogy }\end{array}$ & 30 & 278 & $\begin{array}{l}\text { Students } \\
\text { diverse } \\
\text { population/low } \\
\text { income }\end{array}$ \\
\hline $\begin{array}{l}14^{\text {th }} \\
\text { Kindergarten } \\
\text { of Sykies }\end{array}$ & public & Yes & $\begin{array}{l}\text { Learner-Centred } \\
\text { Pedagogy }\end{array}$ & 2 & 21 & $\begin{array}{l}\text { Students } \\
\text { diverse } \\
\text { population/low } \\
\text { income }\end{array}$ \\
\hline
\end{tabular}

Based on one of the ISOTIS project's expectations that by using heritage languages in early education will stimulate children's language awareness, multicultural attitudes and language and literacy development, a transferable prototype program for early childhood and primary school classrooms to support multi-cultural and multilingual competences among children, 
using ICT-technology and Virtual Learning Environment educational platforms.

The relevant literature indicates that innovative strategies in the classrooms support learning in today's multimodal communication environments while they aim to reduce educational and social inequalities focusing on curriculum, pedagogy, and school climate.

According to the experiences gained from previous work within the ISOTIS project, we have to highlight the arguments (subjects or themes) that we have as a guide to plan and implement the activities for Virtual Learning Environment (VLE), to promote coexistence with other cultures and interaction, brought together with self-esteem and self-confidence.

The aims of the VLE activities developed in the ISOTIS context were:

- to equip the children with the experiences and the perspectives needed to enable them to become citizens of the world;

- to enrich the curriculum and change from monocultural to intercultural, with an extended view and critical stance;

- to develop children's and parents' critical thinking;

- to raise the importance of sharing knowledge on different languages and cultures and the equal importance of all languages;

- to recognize and show respect for similarities and differences across the curriculum;

- to learn about identities and the things that contribute to our identity, including our membership of different groups;

- to learn about their languages and the importance for them, so as to recognize themselves, their culture and their language in the program;

- to develop strategies to deal with prejudice, including racism, and to support others who encounter it.

It is also important to mention and take into consideration that innovation requires openness and interactions between systems and their environments (OECD, 2016). As education is perceived in most countries as a means of enhancing equity and equality, innovations could help enhance equity in the access to and use of education, as well as equality in learning outcomes.

More specifically, we designed our activities so that they would meet the following criteria of ISOTIS values and innovative methods:

- Empowering interconnections among participants/ individuals' systems (e.g., family, school/organization, extended community...)

- Process-oriented: activities should not be intended and designed as isolated-segmented activities; rather they should be part of a meaningful process including several steps, connected to the local systems of life of the participants. 


\section{Macrothink}

- Culturally sensitive and developing cultural sensitiveness.

- Innovative.

- Pragmatic (offering examples) and open to local adjustments.

The common perception that arose from our meetings, focusing on the activities we planned, can be succinctly described below:

- to create a flexible space that can easily be adjusted to provide support for the learning activities

- the activities would allow for various groupings and school subjects integration, including Arts

- the activities and pedagogical approaches would support social interaction and development as cognitive skills

- to further support the integration of technology

- to provide opportunities for students to learn through examples

\section{Main Issues/Challenges and Arguments for Co-Design Phase}

The main challenges that arose from the exploratory phase of this particular study as challenges to our intervention program, were:

- Parents' stereotypes: as many parents have been educated through standard, traditional teaching/tutoring strategies, new learning processes and approaches may confuse them. Additionally, most of them are not familiar with ICT for educational purposes (see Note 2), in order to achieve the aims of V.L.E. that focus in learning but also for sharing, teaching, documenting, communicating.

- Another issue that arose refers to the 'intercultural context' of the program, that made some parents, that are politically against immigrants and refugees, to ask to 'make surface approaches' talking about these 'things' (two parents expressed relevant requests).

- An additional issue concerns the curriculum that is highly fragmented in the Greek elementary school. Teachers were highly concerned about covering the curriculum's timeline for all the major subjects and were sceptical on the time needed for the implementation of the VLE activities. There was an agreement to implement ISOTIS activities on 'Flexible Zone' framework (for Year 1 class is 3 hours per week). The researchers made suggestions to integrate these activities into curriculum subjects as language and art.

- According to children's needs, from data collected in December, we had to plan and organize activities that should meet ISOTIS criteria and respond to children's needs: the activities should be developed through the collaboration and dialogue between teachers and students, should be based on their experience, challenging stereotypes, 
and targeting at building healthy relationship with others.

By viewing teachers as social actors, we present the main goals of ISOTIS focusing on the aims of the activities and on general criteria so that the activities could:

- promote dialogue that raises and challenges different views about identity, stereotypes

- increase the knowledge of other cultures and deal with multilingualism and multiculturalism

- teach students to act as critical citizens and to deal with multiculturalism.

During the interviews teachers showed/expressed a great interest for the activities. As one teacher said: 'in our children's education we must focus on how they can become critical citizens that respect difference and work to make their environment a better and safer place to be and work in' (Teacher A). Another teacher argued that: '...to increase children's knowledge and skills we first have to focus on creating a safe environment in class and in the family so that everyone can have a feeling of worth and value' (Teacher B).

A parent in the meeting, that represented the parents of one class, fully agreed: 'what I want for my child is not only to get a basic education but for them to be valuable members of the society, with their family, friends, and people who they will work with in the future' (a member of the parents' committee).

The researchers pointed out the basic axes of activities and the teachers had to focus on the materials and educational tools that address the criteria agreed.

Teachers' general agreement was that: 'we feel valuable, we feel that our opinion matters when we are asked to have a critical and active role in the activities' (Teacher B). Another teacher points out: 'I know my class very well. Not everything is for everyone, and we must be flexible of what to use and how to use it' (Teacher A).

A pilot implementation of the activities that took place in two schools by both the researchers and the teachers was used as a guideline for the materials and educational methods we had to use in our co-design activities. Two activities, one for each school, were implemented in classes. The findings from the observation of children's reactions and interpersonal relations were used as guidelines for the co-design of the activities.

The activities:

(a) Challenged their beliefs (some of them with stereotypes and prejudices) and made them experience 'cognitive conflict' that, ultimately helps them build their own knowledge to interact in peaceful ways, to respect others and find ways to live in a peaceful world. There were 'underlying beliefs' about 'others', viewing the 'other' as 'stranger', 'an annoying person', 'a different person that has to learn', 'a scary one".

(b) Through the creative use of the multilingualism, the intercultural cooperation amongst the children, the participation of the families and their communities, we raised the children's "bilingual awareness" as they discovered the various advantages of bilingualism for all. The 
activities aim at promoting multiculturalism and utilizing linguistic and cultural diversity tools in the kindergarten and raises and challenges different aspects of the matter at hand.

Table 3 highlights the main principles and shared ideas that arose from meetings according to ISOTIS criteria, teachers experience and children's needs. The 'Identity' of activities highlights the process of activities to be implement and lies on our theoretical approach of citizenship education. The main idea was to work with feelings, attitudes and possible stereotypes and prejudices and to transform them though the life experiences that children and teachers bring into class. It is also important to acknowledge that this work is going to be used as a guide in order to develop and decide the materials to be used.

Table 3. The main principles and shared ideas regarding according to ISOTIS criteria, teachers' experience and children's needs

\begin{tabular}{|c|c|c|c|}
\hline $\begin{array}{l}\text { 'IDENTITY' } \\
\text { of activity }\end{array}$ & Aims & Main procedures & Learning outcomes \\
\hline $\begin{array}{l}\text { we belong to } \\
\text { wider } \\
\text { community }\end{array}$ & $\begin{array}{l}\text { learning about } \\
\text { different } \\
\text { communities, } \\
\text { including family } \\
\text { and school } \\
\text { to discuss and } \\
\text { communicate } \\
\text { their feelings and } \\
\text { opinions about } \\
\text { their } \\
\text { communities } \\
\text { to recognize and } \\
\text { respect diversity } \\
\text { within their } \\
\text { communities to } \\
\text { work in pairs or } \\
\text { small groups to } \\
\text { share their views }\end{array}$ & $\begin{array}{l}\text { children } \\
\text { announce what } \\
\text { they like or } \\
\text { dislike about } \\
\text { school } \\
\text { community } \\
\text { they write down } \\
\text { small texts or } \\
\text { words, or } \\
\text { drawing pictures } \\
\text { that describe } \\
\text { how their school } \\
\text { likes } \\
\text { they found out } \\
\text { different } \\
\text { members of their } \\
\text { school } \\
\text { community, } \\
\text { activities, rules } \\
\text { and members of } \\
\text { the wider } \\
\text { community } \\
\text { (neighborhood) } \\
\text { make a list of } \\
\text { members belong }\end{array}$ & $\begin{array}{l}\text { recognize and } \\
\text { respect diversity } \\
\text { within their } \\
\text { local } \\
\text { community } \\
\text { - understand that } \\
\text { they belong to } \\
\text { different groups } \\
\text { and } \\
\text { communities, } \\
\text { including school } \\
\text { and family } \\
\text { discuss and } \\
\text { express their } \\
\text { feelings using } \\
\text { different } \\
\text { language }\end{array}$ \\
\hline
\end{tabular}




\begin{tabular}{|c|c|c|c|}
\hline & & $\begin{array}{l}\text { in different } \\
\text { communities } \\
\text { recognizing that } \\
\text { some are } \\
\text { members of } \\
\text { some } \\
\text { communities and } \\
\text { some not but also } \\
\text { the links to each } \\
\text { community } \\
\text { they make a } \\
\text { portrait or } \\
\text { picture of their } \\
\text { home and write } \\
\text { down words that } \\
\text { describe it (in } \\
\text { different } \\
\text { languages) } \\
\text { Invite parents } \\
\text { and members } \\
\text { from different } \\
\text { communities and } \\
\text { cultural } \\
\text { backgrounds to } \\
\text { talk about their } \\
\text { home } \\
\text { Visit places from } \\
\text { different culture }\end{array}$ & \\
\hline $\begin{array}{l}\text { The world we } \\
\text { live in }\end{array}$ & $\begin{array}{l}\text { Learning about } \\
\text { different places, } \\
\text { drawing on their } \\
\text { own and others' } \\
\text { experience } \\
\text { - to devise an } \\
\text { enquiry into life } \\
\text { in another type } \\
\text { of community } \\
\text { that there are } \\
\text { similarities, as } \\
\text { well as }\end{array}$ & $\begin{array}{l}\text { children identify } \\
\text { on maps } \\
\text { different places } \\
\text { they have visited, } \\
\text { been on holiday } \\
\text { to, lived in, or } \\
\text { where they have } \\
\text { relatives They } \\
\text { discuss what } \\
\text { they think the } \\
\text { similarities and } \\
\text { differences are } \\
\text { between living in }\end{array}$ & 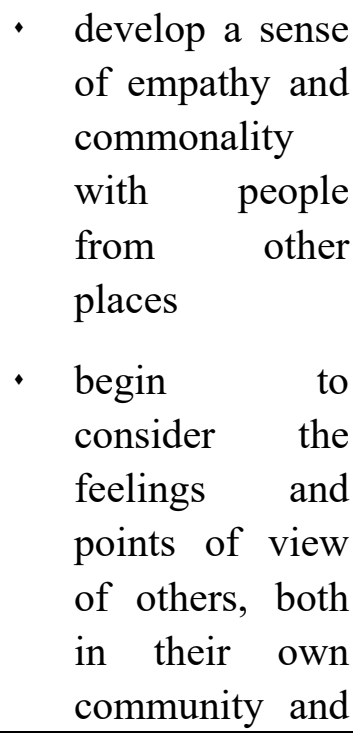 \\
\hline
\end{tabular}




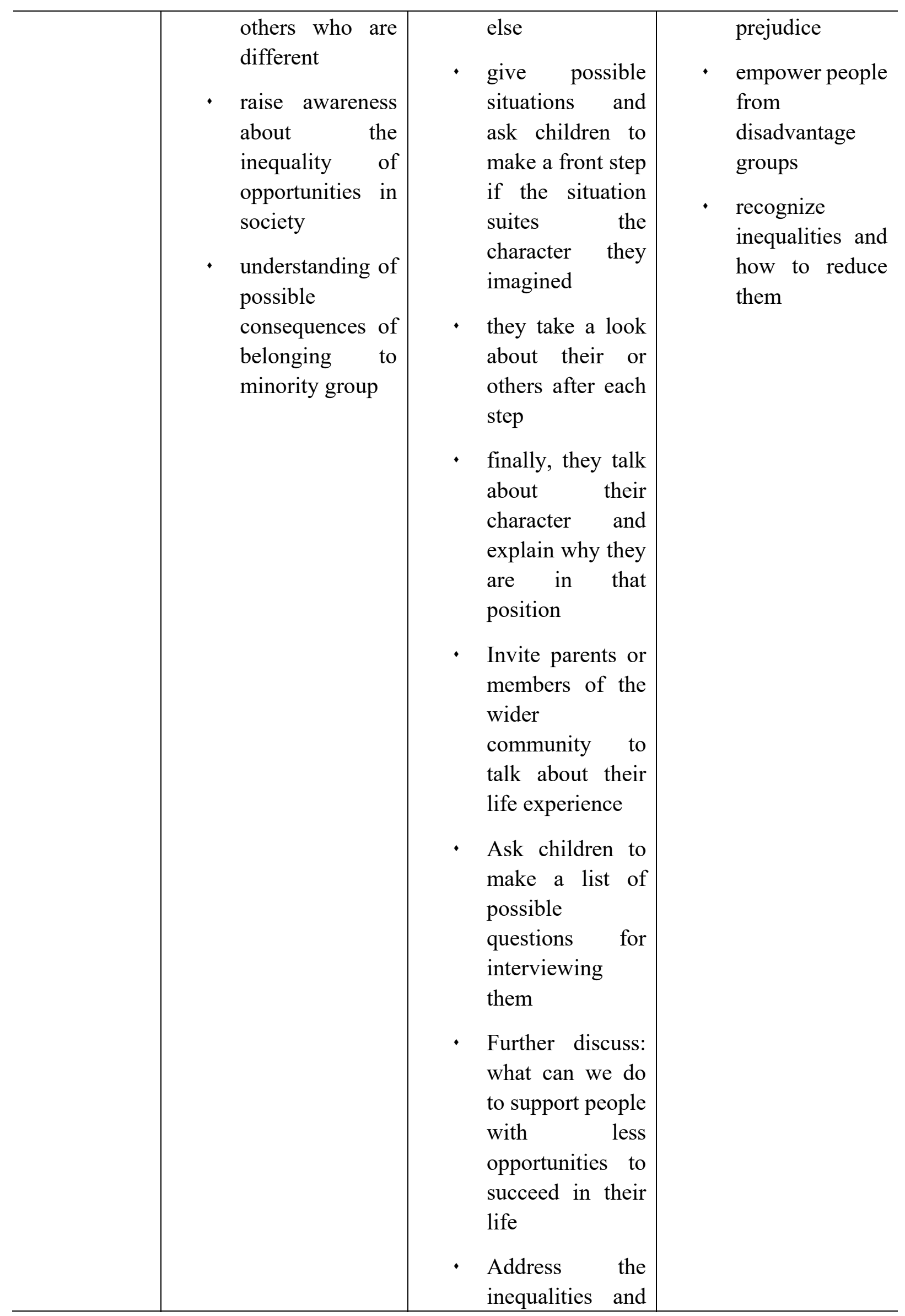




\begin{tabular}{|c|c|c|c|}
\hline & & $\begin{array}{l}\text { possible } \\
\text { solutions }\end{array}$ & \\
\hline $\begin{array}{ll}\text { Real world } & \text { wsues }\end{array}$ & $\begin{array}{l}\text { - Connecting } \\
\text { school with } \\
\text { broad } \\
\text { community } \\
\text { - Improve } \\
\text { dialogue through } \\
\text { members of the } \\
\text { school } \\
\text { community and } \\
\text { beyond } \\
\text { Understanding } \\
\text { real world issues }\end{array}$ & $\begin{array}{l}\text { Provide a video } \\
\text { with real world } \\
\text { issues (poverty, } \\
\text { immigration, } \\
\text { inequalities } \\
\text { between genders, } \\
\text { stereotypes etc) } \\
\text { Start a dialogue } \\
\text { based in } \\
\text { questions like } \\
\text { What happened? } \\
\text { Who are the actors? } \\
\text { How the act or react. } \\
\text { Where? } \\
\text { Why? } \\
\text { What is the solution? } \\
\text { Find possible solutions. } \\
\text { Ask members of } \\
\text { the community } \\
\text { to share ideas } \\
\text { and give their } \\
\text { opinion }\end{array}$ & 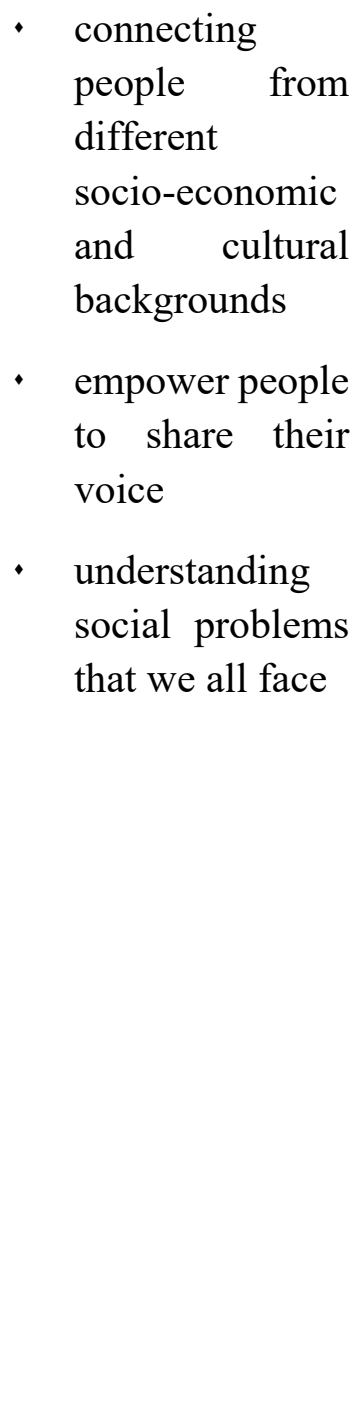 \\
\hline
\end{tabular}

\section{Conclusion}

As the teachers pointed out, they were helped to learn about different communities, to discuss their feelings and share opinions. They agreed, as the parents did, that they could recognize and respect diversity, to explore and learn about different cultures and ways of thinking and they were able to understand other's views. The material and the VLE platform gave an opportunity to develop empathy and respect for others, to minimize stereotypes and empower people from disadvantaged groups. The material seemed that help to reach a better approach of minority groups empowerment and children's involvement with social content. It remains to be explored in what extent the platform and the social activities can really help people from different back grounds to be better integrated. A prototype ICT-based curriculum intervention can be developed fostering an inclusive approach to diversities in the early years. Therefore, our findings highlight a priority for further development in existing educational practices and 
policies tackling inequalities. There is room for further development of family involvement practices within school interventions and practices and also supporting professional skills through a design-based research.

\section{Acknowledgement}

The research is part of the ISOTIS project (www.isotis.org) which has received funding from the European Union's Horizon 2020 research and innovation programme under grant agreement No. 727069.

\section{References}

Baldwin-Edwards, M. (2005). Migration in the Middle East and in the Mediterranean. A Regional Study prepared for the Global Commission on International Migration. Athens: Mediterranean Migration Observatory.

Banks, J. A. (2008). Diversity, Group Identity and Citizenship Education in a Global Age. Educational Researcher, 37, 129-139. https://doi.org/10.3102/0013189X08317501

Bronfenbrenner, U., \& Morris, P. A. (2006). The bioecological model of human development. In R. M. Lerner (Ed.), Handbook of child development (Vol. 1. Theoretical models of human development, pp. 793 - 828). Hoboken, NJ: Wiley.

Flouris, G., \& Passias, G. (2003). A critical appraisal of curriculum reform in Greece (1980-2002) European Education, 35-90. https://doi.org/10.2753/EUE1056-4934350373

Gropas, R., \& Triandafyllidou, A. (2005). Migration in Greece at a glance. Hellenic Foundation (Overview based on the Country Report prepared for the project POLITIS: Building Europe with New Citizens?). Athens: ELIAMEP. [Online] Available: http://www.eliamep.gr/wp-content/uploads/en/2008/10/migration.pdf

Institute of Educational Policy. (2014). The curriculum of kindergarten (Revised edition). New School (the school of 21st century) - The new curriculum. Athens: Institute of Educational Policy -Hellenic Ministry of Education [in Greek]. [Online] Available:

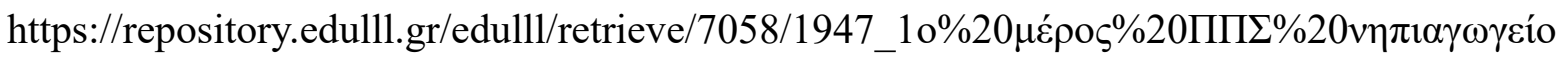
v.pdf

Kasimis, C., \& Kasimi, C. (2004). Greece: A History of Migration. Migration Policy Institute. [Online] Available: http:/www.migrationinformation.org

Lazaridou, A., \& Kassida, G. A. (2015). Involving parents in secondary schools: principals' perspectives in Greece. International Journal of Educational Management, 29(1), 98-114. https://doi.org/10.1108/IJEM-06-2013-0102

May, S. (1999). Critical Multiculturalism and Cultural Difference: Avoiding Essentialism. In S. May (Ed.), Critical Multiculturalism. Rethinking Multicultural and Antiracist Education (pp. 11-41). London: Falmer Press Taylor \& Francis Group.

May, S., \& Sleeter, C. E. (Eds.) (2010). Critical multiculturalism: Theory and praxis. London: 
Routledge. https://doi.org/10.4324/9780203858059

McLaren, P. (2003). Life in schools: An introduction to critical pedagogy in the foundations of education (4th ed.). Albany, NY: Allyn \& Bacon.

National Statistical Service of Greece (2001). Statistical Yearbook 2001. Athens: NSSG. [in Greek]

Nieto, S. (1999). Critical multicultural education and students' perspectives. In S. May (Ed.), Critical multiculturalism. Rethinking multicultural and antiracist education (pp. 191-215). London: Falmer press, Taylor \& Francis Group.

OECD. (2016). Innovating Education and Educating for Innovation: The Power of Digital Technologies and Skills. Paris: OECD Publishing. http://dx.doi.org/10.1787/9789264265097-en

Scientific Committee in Support of Refugee Children. (2017). Refugee Education Project - A. Assessment Report on the Integration Project of Refugee Children in Education (March 2016-April 2017) - B. Proposals for the Education of Refugee Children during the 2017-2018 School Year. [Online] Athens. Available: https://www.minedu.gov.gr/prosf-ekpaideusi-m/29182-06-07-17-scientific-committee-in-sup port-of-refugee-children-refugee-education-project-a-assessment-report-on-the-integration-pr oject-of-refugee-children-in-education-march-2016-april-2017-v-proposals-for-the-education -of-refugee-children-during-the-2017-2018-school-year-athens-april-2017

Sleeter, C. E., \& Grant, C. A. (1994). Making choices for multicultural education: Five approaches to race, class, and gender. New York, NY: Macmillan.

Triandafyllidou, A., \& Mantanika, R. (2016). Migration in Greece: Recent Developments in 2016. Report prepared for the OECD Network of International Migration Experts (formerly SOPEMI). Global Governance Program European University Institute. [Online] Available: http://www.eliamep.gr/wp-content/uploads/2014/10/2016.pdf

UN Migration. (2019). IOM in Greece. [Online] Available: https://www.iom.int/countries/greece

Xenitidou, M. (2007). Talking about Greek national identity and immigrant integration in Central Northern Greece: the extension of Greekness as the ultimate contract for migration?. Paper presented at the LSE PhD Symposium "Contemporary Greece: Structures, Context and Challenges", 14-15 June, London.

\section{Notes}

Note 1. The school policy of $16^{\text {th }}$ Primary School of Evosmos-Thessaloniki is presented in http://16dim-evosm.thess.sch.gr/?cat=106.

Note 2. In fact, only after a lot of efforts a number of parents started to use their e-mail so as to be informed by school site instead of receiving notification letters. 


\section{Macrothink}

International Journal of Learning and Development

ISSN 2164-4063 2020, Vol. 10, No. 1

\section{Copyright Disclaimer}

Copyright for this article is retained by the author(s), with first publication rights granted to the journal.

This is an open-access article distributed under the terms and conditions of the Creative Commons Attribution license (http://creativecommons.org/licenses/by/4.0/). 